\title{
Study of the measurement and stability estimation of concrete roadbed slab at high-speed train in bridge- earthwork transition zone
}

\author{
Kim, Taekyun ${ }^{1}$, Choi, Byeongjin ${ }^{2}$, Park, Jongho ${ }^{3}$, Hong, Sungnam ${ }^{4,}{ }^{*}$, Park, Sun-Kyu ${ }^{5}$ \\ 1, 2, 3, 4, 5 Sungkyunkwan University, South Korea
}

\section{Index Terms}

Bridge-Earthwork Transition Zone Measurement

Stability

High-Speed Train

Received: 19 October 2014

Accepted: 20 July 2015

Published: 26 April 2016

\begin{abstract}
Recently, many countries are interested in the development of high-speed trains. However, compared to high-speed train technology developing, the high-speed train infra system is not verified. Furthermore, in the case of bridge-earthwork transition zone that is the most complicated in railroad facility track, bridge-earthwork is connected complicatedly. Disorder and destruction of track can be occurred by rigidity transition. To apply a high-speed train with $430 \mathrm{~km} / \mathrm{h}$, it is needed to evaluate the stability of behavior condition of bridge-earthwork transition zone by instrumentation system and the construction methods that are accurately and consistently verifiable. In this study, vertical displacement of bridge-earthwork that connects pre-stressed concrete box bridge and earthwork zone is calculated theoretically and evaluates stability compared with measurement of wheel load, strain, displacement data with estimation data, and measurement criteria. Therefore, compared to wheel load, strain, displacement data with estimation data and measurement criteria, the stability showed favorable results.
\end{abstract}

(C) 2016 The Author(s). Published by TAF Publishing.

\section{INTRODUCTION}

The advanced countries, including U.S.A are recognizing the need of the railroad industry development in order to plan the transportation in large volume because of the conquest international economic crisis and industrial development and population increase. In addition, the paradigm of the transportation system construction for the development of state fitted for the low carbon green growth has changed so that the movement for expansion of investment for the railroad is globally increased more than

\footnotetext{
*Corresponding author: Hong, Sungnam

E-mail: cama77@nate.com
}

the vehicle road. In Korea, railroad industry which is developed faster than train or railroad system is interested to improve the international competitive ability and reduce the logistic cost. And the goal connecting the whole country within an hour and a half that is about daily commuting time by 2020 was announced. Accordingly, the next generation high-speed train of $430 \mathrm{~km} / \mathrm{h}$ class was developed. But the rapid transit railroad infra system didn't have many interests till the recent compared with the rapid transit railroad vehicular (High-speed train) technology. Consequently, the developments of the optimized design standard and core technology of railroad infrastructure were not developed. In the advanced 
countries, the observation and measuring technique are continuously developed and it is applying to the civil structure overall and propagating. And they are making an effort to build the long-term monitoring system (e.g. sensor, wireless system, power harvesting and etc.) in order to evaluate the structure state more objectively. As to especially, the rapid transit railroad that was supported the train drives at the high-speed over $400 \mathrm{~km} / \mathrm{h}$, the stability and high serviceability are required to support track structures as rail, sleeper, ballast stone, concrete bed and road bed.

Moreover, the small defect will become bigger by the impulsive load or shock that was occurred during high speed driving and accidents happen including the suspension of service or derailment, etc. Especially the railroad structure connection with concrete bed at the bridge-earthwork transition zone is one of the parts, which is most complicated structure in the railroad infrastructure. It is also vulnerable section which may be easily occurred during roadbed settlement and deformation of railroad structure by differential settlement in railroad structures at transition zone according to sudden change of support rigidity [1] and [2].

Therefore, in this research, the behavior of the concrete roadbed slab in bridge-earthwork transition zone was induced by theory and compared with real behavior (value by monitoring system) and criteria of management reference to evaluate track support rigidity and driving stability of train [3] and [4].

\section{A. Track Support Rigiditiy}

In the case of the track based on concrete roadbed, the elastic function is the important factor including the structural performance of track, the durability life, noise, vibration, etc. Moreover, in the service function, the uniform strength of roadbed, which is possible and continuity of track rigidity had to be maintained. Therefore, in order to have similar elastic modulus on both sides of the connection section at bridge-earthwork transition zone, it needs to be considered in design [5] and [6].

To evaluate stability of test-bed which was applied with technology of $400 \mathrm{~km} / \mathrm{h}$ class high-railroad infrastructure, connection with PSC Box Bridge and soft ground were selected. The rail fastening device which was used for tracking concrete roadbed in the test-bed was Vossloh System 300-1 and 300W. The settlement and track support rigidity were calculated based on properties 300-1 and $300 \mathrm{~W}$.The value of properties of each rail fastening devices was shown in the table 1 . Static rigidity value of the rail fastening system was used to test value in the test certification of SNCF (Societe Nationale des Chemins de fer Francais). The bridge-earthwork connection at transition zone was possible to change deformation of section and had the complicated behavior which was moved the contact point between rail and wheel, so impact coefficient of 2 was used for designing load of dynamic wheel load. The UIC 60 used in EU was shown in figure 1 [7] and [8].

TABLE 1

INPUT DATA FOR RIGIDITY

\begin{tabular}{|c|c|c|}
\hline & Category & Input data \\
\hline \multirow[t]{4}{*}{ Rail } & Type & UIC 60 (60EI) \\
\hline & Mass & $78.5 \mathrm{~kg} / \mathrm{m}$ \\
\hline & Elastic modulus & $2.1 \times 10$ \\
\hline & Moment of inertia & $30.55 \times 10^{6} \mathrm{~mm}^{4}$ \\
\hline \multirow[t]{4}{*}{$\begin{array}{l}\text { Support } \\
\text { Rigidity } \\
\text { (static/dynamic) }\end{array}$} & $\begin{array}{l}\text { Vossloh System 300-1 } \\
\text { (Transition zone } 1 \text { and 2) }\end{array}$ & $\begin{array}{l}37 / 44 \mathrm{kN} / \mathrm{mm} \\
33 / 40 \mathrm{kN} / \mathrm{mm}\end{array}$ \\
\hline & $\begin{array}{l}\text { Vossloh System 300w } \\
\text { (Earthwork) }\end{array}$ & $31 / 40 \mathrm{kN} / \mathrm{mm}$ \\
\hline & Design Axial Load (P) & 14tf (HEMU 430x) \\
\hline & Design Dynamic Wheel Load (Q) & 28tf (HEMU 430x) \\
\hline
\end{tabular}

ISSN: 2414-4592 


\section{A. Support Rigidity Formula}

The formula using track support rigidity at bridgeearthwork transition zone was shown through equation
(1) and (2). These equations were based on continuous welded rail over support of longitudinal truss rigidity in longitudinal direction. This support is consisted of ballast, roadbed and sleeper [9].

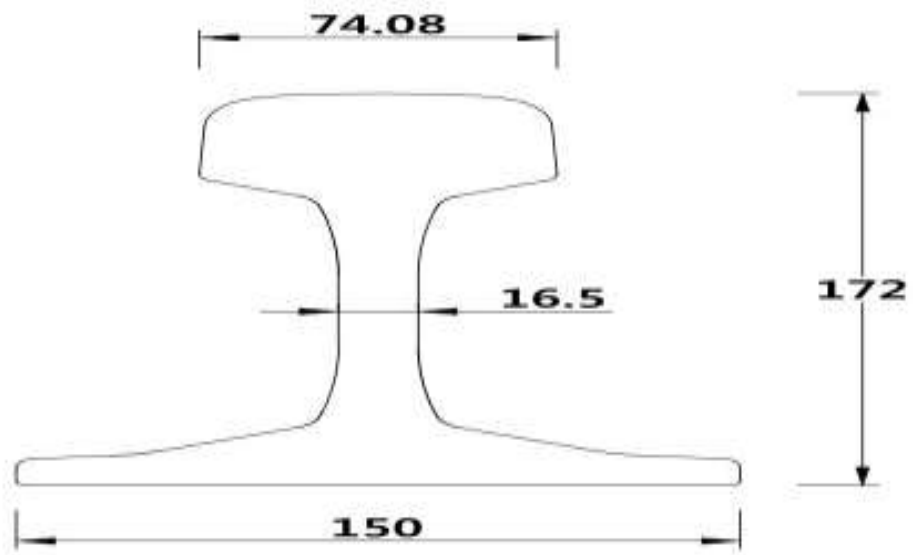

Fig. 1. Section specification of UIC 60

$K_{\text {stat } / d y n}=\sqrt[4]{\left(\frac{4 C_{c}}{a}\right)^{3} E I}$

Then, $\mathrm{K}$ (Track rigidity)

$\mathrm{C}_{c}$ (Support point rigidity)

a (Spacing of sleeper)

$y_{0}=Q / K$

Then, $\mathrm{Q}$ (Wheel force, $\mathrm{P} / 2$ )

\section{RESULT OF CALCULATION}

The vertical displacements (settlement) according to the rigidity of connection section and earthwork part were shown in the table 2 and figure 2.

The spacing of sleeper and total static rigidity in direction transition zone (PSC Box Bridge) to earthwork were decreased from $650 \mathrm{~mm}$ to $600 \mathrm{~mm}$ and from $93.3 \mathrm{kN} / \mathrm{mm}$ to $86.7 \mathrm{kN} / \mathrm{mm}$ respectively. The total vertical displacement increased about $0.11 \mathrm{~mm}$ from $1.47 \mathrm{~mm}$ to $1.58 \mathrm{~mm}$. These results can be forecasted to satisfy recommendation design criterion of 0.3 and do not need to be considered for the additional evaluation for design in bridge-earthwork transition zone [10] and [11].

TABLE 2

RESULT OF CALCULATION

\begin{tabular}{ccccc}
\hline \hline Category & Unit & Transition Zone & Transition Zone & \multirow{2}{*}{ Earthwork } \\
\hline $\begin{array}{c}\text { Fastening } \\
\text { Device } \\
\text { Length } \\
\text { Total }\end{array}$ & - & 1 & 2 & Vossloh System \\
Track Support & $\mathrm{M}$ & 10 & 10 & $300 \mathrm{~W}$ \\
$\begin{array}{c}\text { Rigidity } \\
\text { Spacing of } \\
\text { Sleeper }\end{array}$ & $\mathrm{kN} / \mathrm{mm}$ & 93.3 & 90.9 & 86.7 \\
$\begin{array}{c}\text { Static Rigidity } \\
\text { Vertical } \\
\text { displacement } \\
\text { (Settlement) }\end{array}$ & $\mathrm{kN} / \mathrm{mm}$ & 650 & & \\
\hline \hline
\end{tabular}




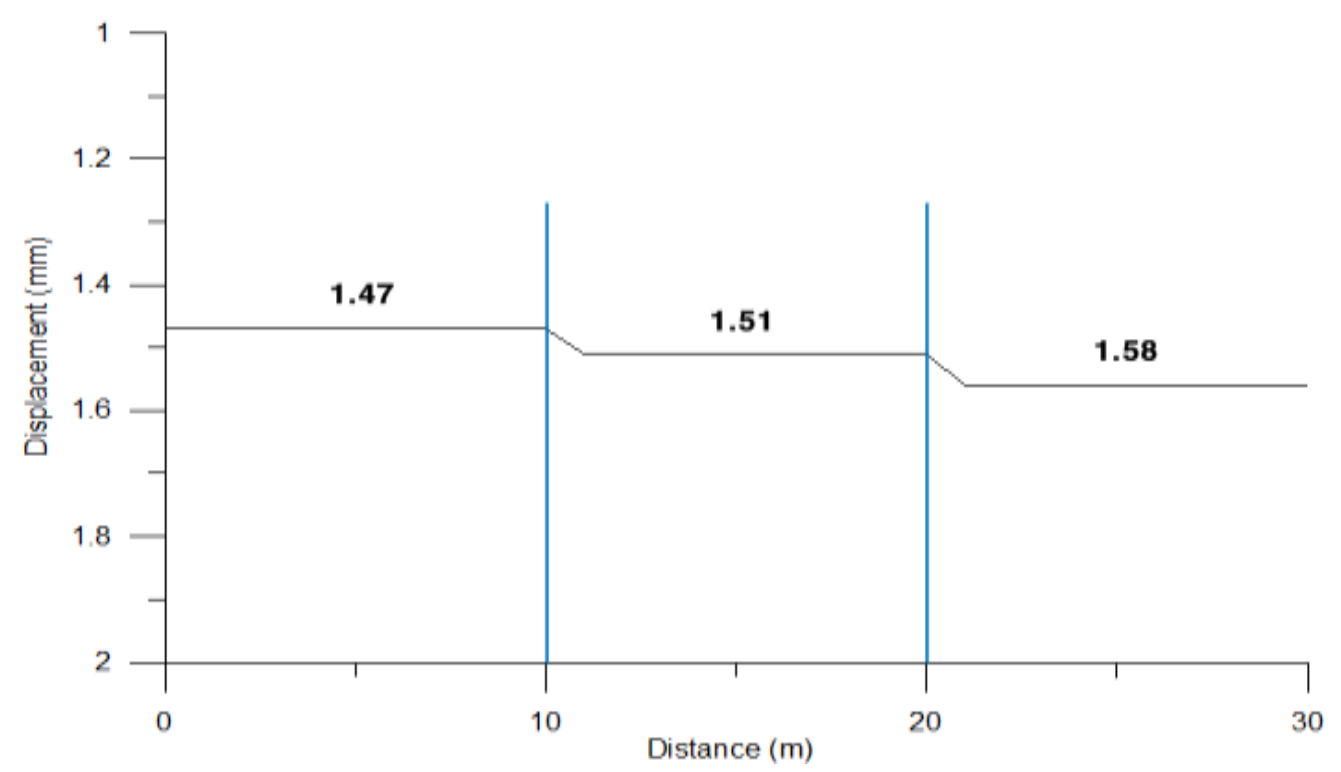

Fig. 2. Vertical displacement (Settlement) by formula

\section{MONITORING}

The concrete roadbed slab which is the part of bridge and earthwork at transition zone was decided for research site to evaluate the stability on service state of maximum speed and variable operating speed in high-speed train. And monitoring data from transition zone were collected. The research site is the soft ground, which is dramatically changed with the support rigidity coefficient from the top TCL slab to the sub soft ground. It also had the problem of large amount of wheel force variable, which caused critical issue under construction.

\section{A. Specification Of Monitoring Instrument}

Two of twelve types of monitoring instruments (sensor) were used to measure structure's behavior. The name and specifications of the monitoring instrument (Data logger, strain gauge and displacement meter) were shown in the table $3-5$. When measuring, firstly data recorded in the storage (Throw on data logger) showed No Filtering. And in case the noise was high, the Low Pass Filter more than $1,000 \mathrm{~Hz}$ was used.

TABLE 3

MONITORING INSTRUMENT

\begin{tabular}{lccc}
\hline $\begin{array}{l}\text { Dynamic Data Logger } \\
(\mathrm{CR} 9000 \mathrm{X})\end{array}$ & $\begin{array}{c}\text { Static Data Logger } \\
(\mathrm{CR} 1000)\end{array}$ & $\begin{array}{c}\text { Strain Meter } \\
(\mathrm{KM}-100 \mathrm{~B})\end{array}$ & $\begin{array}{c}\text { Displacement } \\
\text { Meter(500HCA })\end{array}$ \\
\hline
\end{tabular}

TABLE 4

SPECIFICATION OF DATA LOGGER

\begin{tabular}{|c|c|c|c|}
\hline \multicolumn{2}{|c|}{ Category } & \multicolumn{2}{|c|}{ Specification } \\
\hline & & CR9000X & CR 1000 \\
\hline \multirow{2}{*}{ Specification } & Resolution & Within 0.0005 & Over 0.1 \\
\hline & Storage & 2Gbyte & 128Kbyte \\
\hline \multicolumn{2}{|c|}{ Manufacturer } & \multicolumn{2}{|c|}{ Campbell } \\
\hline
\end{tabular}


TABLE 5

SPECIFICATION OF MEASURING INSTRUMENT

\begin{tabular}{|c|c|c|c|}
\hline \multicolumn{2}{|c|}{ Category } & \multicolumn{2}{|c|}{ Specification } \\
\hline \multicolumn{2}{|c|}{ Model } & KM-100B & $500 \mathrm{HCA}$ \\
\hline \multirow{2}{*}{ Specification } & Resolution & $\pm 5,000 \mu \varepsilon$ & $\pm 12.70 \mathrm{~mm}$ \\
\hline & Precision & 1\% RO & $0.2 \%$ RO \\
\hline \multicolumn{2}{|c|}{ Manufacturer } & TML & Schaevitz \\
\hline
\end{tabular}

\section{Location of Installation}

The strain gauge was installed in 8 directions of $45^{\circ}$ in the neutral axis of the rail web. And it was also located beside $100 \mathrm{~mm}$ of between the centers of sleeper. Installation location was shown in figure 3.
TCL (track concrete layer) is the concrete roadbed replacing ballast roadbed and HSB (hydraulically stabilized) is the base that is the reinforcing layer of bottom surface

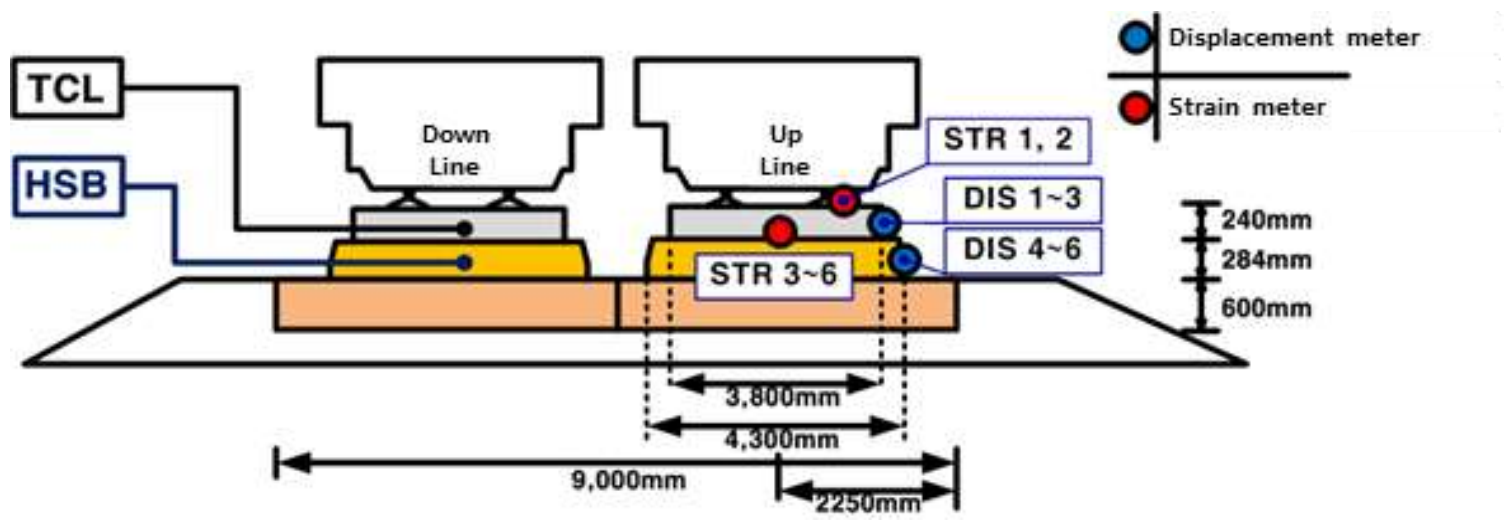

Fig. 3. Front of measuring equipment installation position

Four strain gauges (STR3-6) were installed in the bottom of TCL slab with spacing $2.85 \mathrm{~m}$ based on the concrete roadbed slab at bridge-earthwork transition zone. This was shown in the figure 4 . These locations were based on the upper part of the approach slab where the transition of rigidity happened with a driving of highspeed train in order to figure out the stability and variation of railroad structure. Additionally, it was installed to calculate flexural tensile stress due to deflection from strain of measuring data.

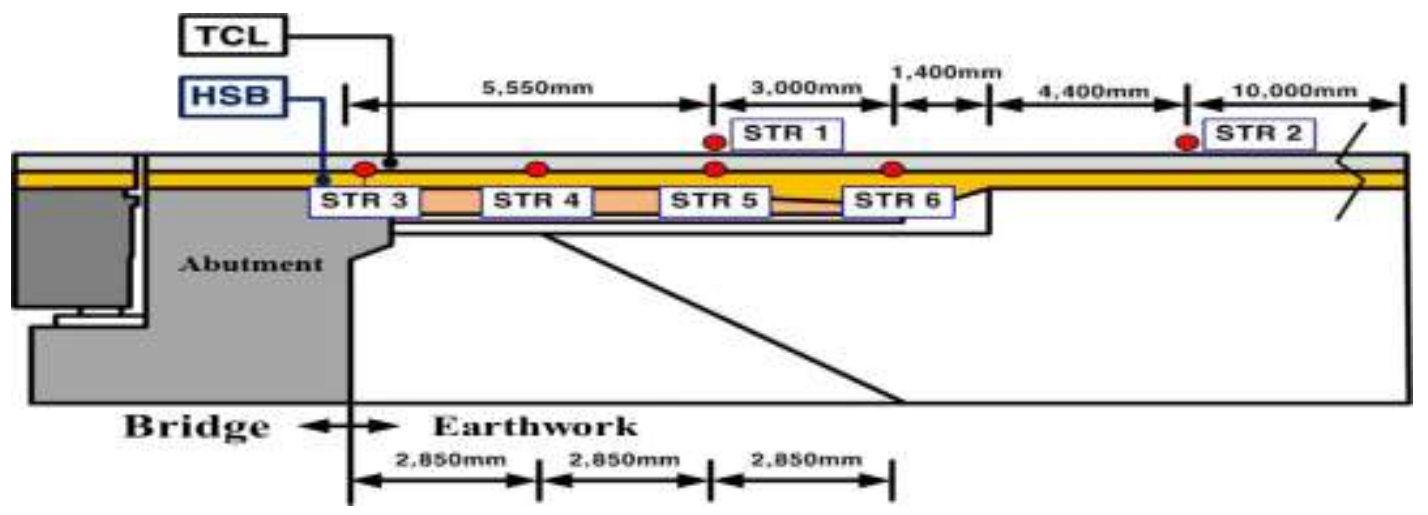

Fig. 4. Side of measuring equipment installation position-strain 


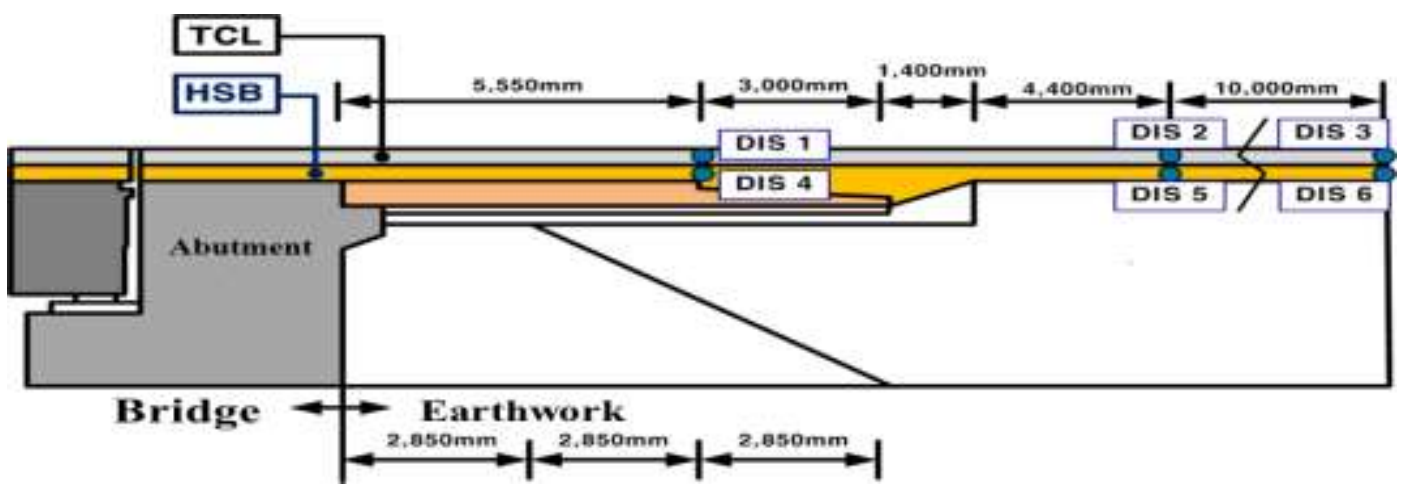

Fig. 5. Side of measuring equipment installation position-displacement meter

The displacement meters were installed three on the center of top approach slab, top of concrete reinforced approach block-earthwork and top of normal earthwork. These locations were shown in the figure 5. When measuring, the train passed through the concrete roadbed slab at bridge-earthwork transition zone with high-speed about over $400 \mathrm{~km} / \mathrm{h}$. So the proper sampling rate was set for the less of data loss. In order to minimize the noise and error of the data and raise the reliability, low pass filter and high pass filter were set.

\section{E. Measuring Process}

The monitoring procedure was performed in the order shown in figure 6. Firstly, the procedure was divided into the previous action step and monitoring step. The former included visual inspection, weather recording of a site and checking malfunction of the sensor and data acquisition. The latter monitoring step was divided into the monitoring according to the train movement and daily monitoring.

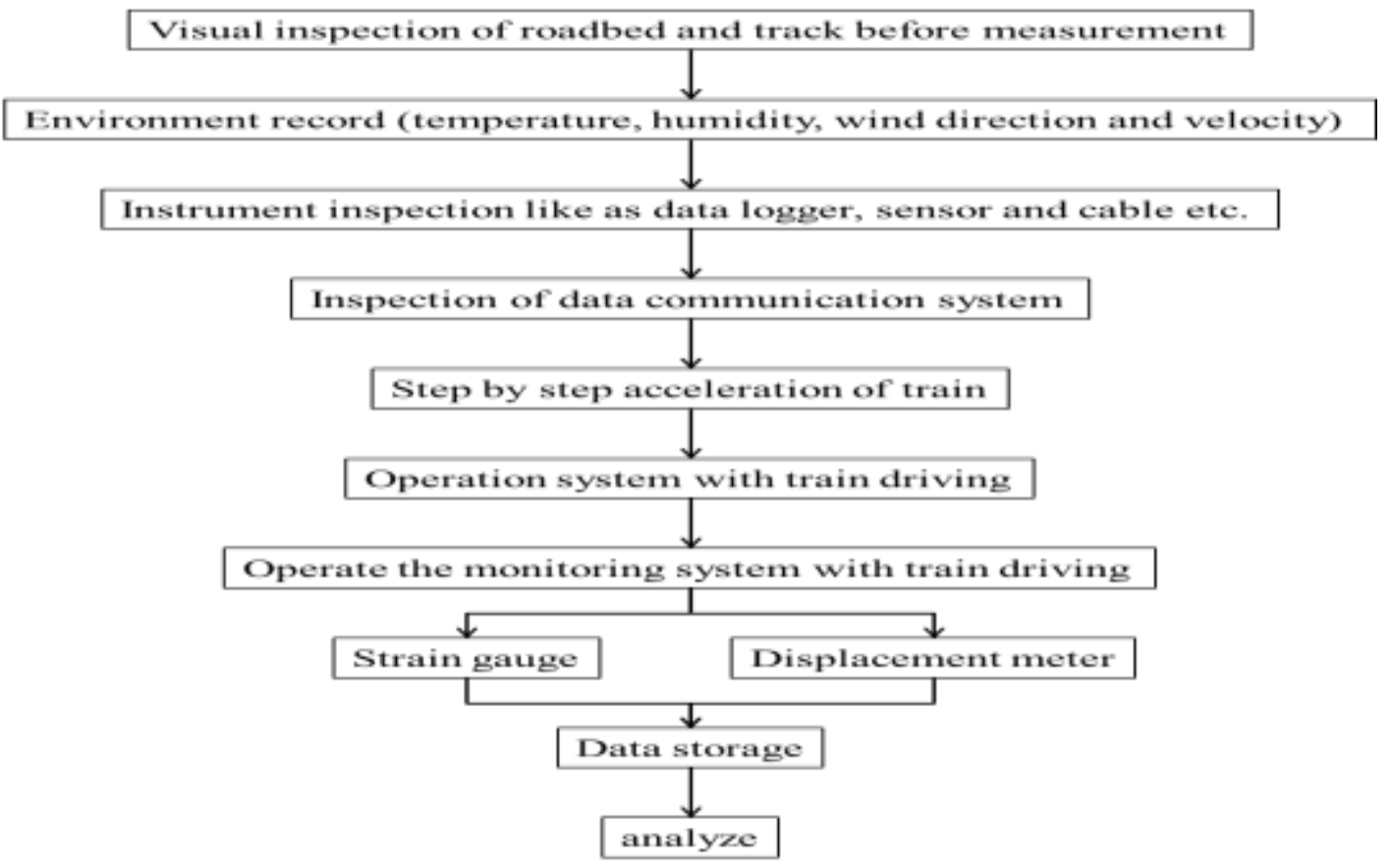

Fig. 6. Monitoring process

\section{F. Criteria of Measurement}

For the concrete roadbed slab at bridge-earthwork transition zone, target of monitoring should be accomplished limit value of displacement and settlement strictly. Especially, the displacement and settlement were important factors for derailment of train. So evaluation of settlement was important also. The criteria of settlement 
of slab, rail wheel force and strain of slab were shown in the table 6. Criterion of strain was presented comparing with criteria of shinkansen in Japan. The strain rate gauge is adhered to TCL slab lower part which was between HSB slab and TCL slab in order to measure bending stress. The criterion of measurement was followed by the driving criterion of Japan, Germany and Korea standard [12] and [13].

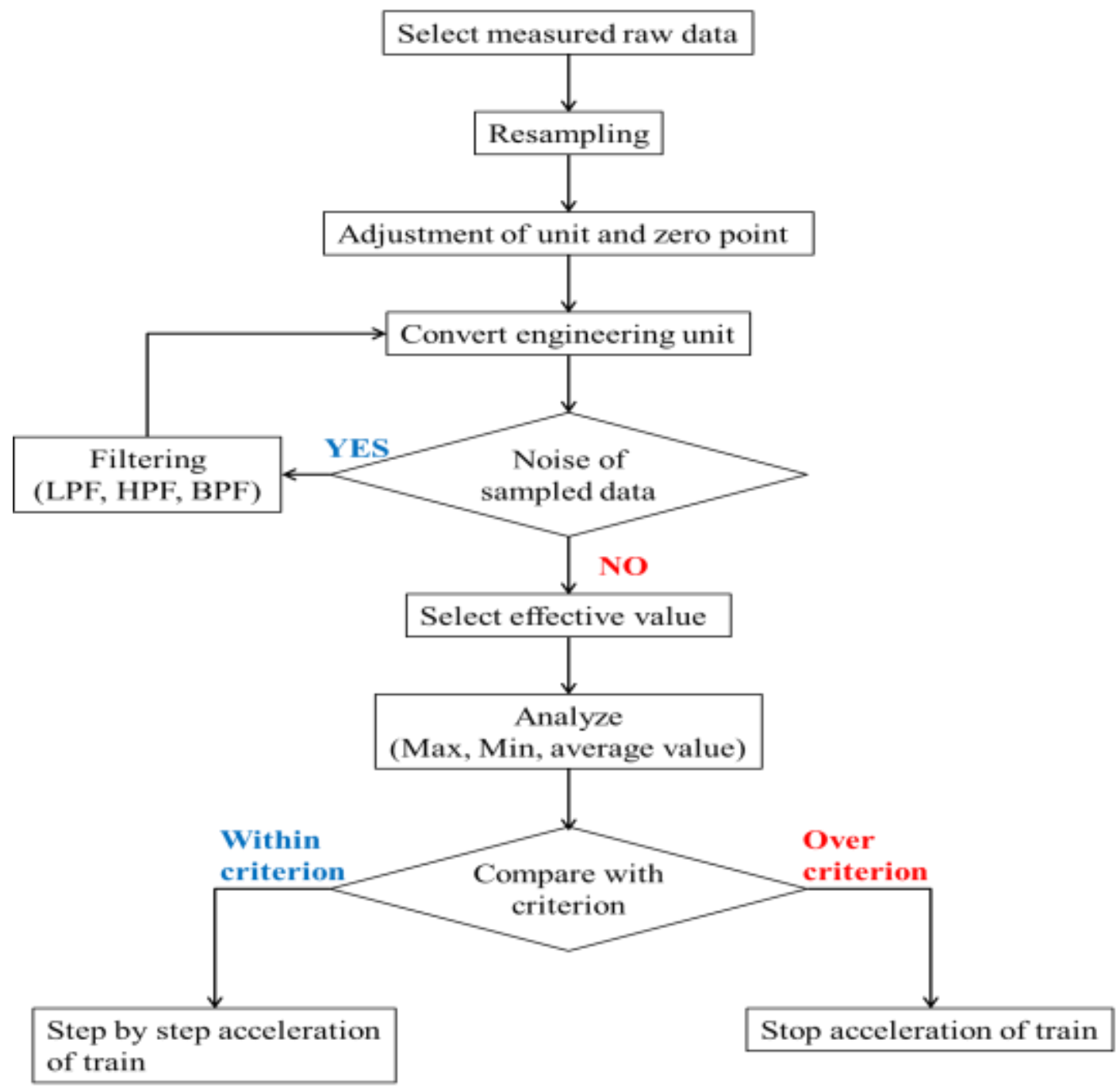

Fig. 7. Algorithm of data conditioning \& processing

TABLE 6

CRITERIA OF MEASUREMENT

\begin{tabular}{cccc}
\hline \hline Subject & Objective & Measurement type & Criterion \\
\hline \multirow{2}{*}{ Track Support } & Top slab & Settlement & $\leq 3 \mathrm{~mm}$ \\
Stiffness & Rail & Wheel force & $\leq 200 \mathrm{kN}$ \\
& TCL Slab & Strain & $\leq 100 \mu \varepsilon$ \\
\hline \hline
\end{tabular}

\section{RESULT \& DISCUSSION}

\section{G. Wheel load}

Wheel load was reaction of track, fixed infrastructure, with the active forces on the vertical direction by passing train. And this force can be measured as value and variable of reaction by monitoring. The variable of wheel force by speed change of train in concrete roadbed slab at bridgeearthwork transition zone was shown in the figure 8. Original monitoring plan was measured at maximum 
speed, $430 \mathrm{~km} / \mathrm{h}$, but the speed of train was $400 \mathrm{~km} / \mathrm{h}$ because the train was made for test.

The pattern of wheel load which was increased gradually to $230 \mathrm{~km} / \mathrm{h}$ with acceleration and after approaching peak point, wheel load was decreased gradually according to the acceleration shown. The cause of decreasing wheel load was decreasing its impact coefficient nevertheless of acceleration of train. This phenomenon may be occurred by the vibration of the vehicle (train), central movement of train, deformation of track and train body and wind pressure according to the acceleration of train.
The article [14] about the reduction of wheel load on running speed was performed to measure the component force by speed acting on the rail with installation of the strain gauge on the rail. Then decreasing value with acceleration was induced by analyzing the output according to the combination forces at various locations with normal direction of the track. Same process was applied to the test-bed, and then $3.9 \mathrm{~kg}$ were decreased according to the increasing $1 \mathrm{~km} / \mathrm{h}$ of speed. This value, $3.9 \mathrm{~kg}$ per $1 \mathrm{~km} / \mathrm{h}$, which was major factor for derailment of train was enough to small value $(0.12$, variation of wheel load) than value $(0.8$, variation of wheel load) of stability criteria. So stability of the test-bed was enough too.

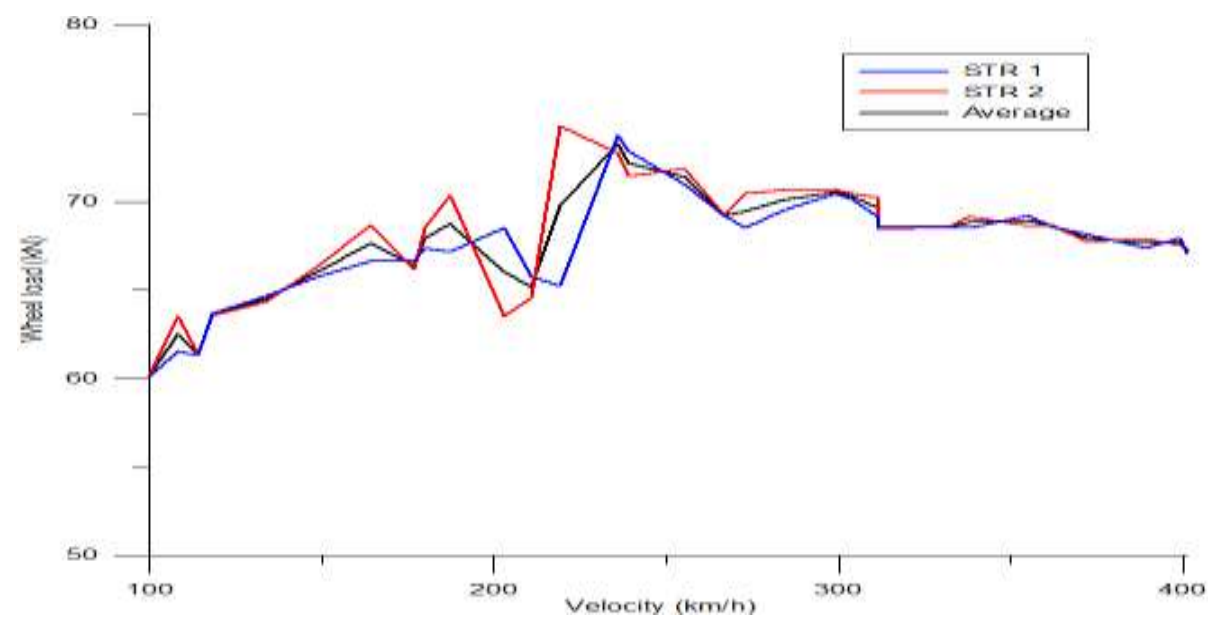

Fig. 8. Wheel Load of driving speed train

In case of calculating the minimum wheel load by using the measured value of STR1 that was $60.134 \mathrm{kN}$ on driving speed of $100 \mathrm{~km} / \mathrm{h}$ was considered. The maximum wheel load was $73.744 \mathrm{kN}$ at $236 \mathrm{~km} / \mathrm{h}$, but actual wheel load was $68.60 \mathrm{kN}$ at test driving. In the other case of STR2, minimum wheel load was $60.144 \mathrm{kN}$ on driving speed of $100 \mathrm{~km} / \mathrm{h}$. The maximum wheel load was $74.265 \mathrm{kN}$ at
$236 \mathrm{~km} / \mathrm{h}$. These values were shown in the table 7. Each maximum value of calculated wheel load was about $34 \%$ of $200 \mathrm{kN}$ which is design standard of maximum wheel load for high-speed railroad structures. Therefore the stability of railroad structure of test-bed for high-speed railroad was enough to perform its design purpose.

TABLE 7

VALUE OF WHEEL LOAD

\begin{tabular}{cccc}
\hline \hline Strain & Max Wheel Load & Min Wheel Load & Average Wheel Load \\
\hline Gauge & $(\mathrm{kN})$ & $(\mathrm{kN})$ & $(\mathrm{kN})$ \\
STR1 & 73.74 & 60.14 & 67.50 \\
STR2 & 74.26 & 60.14 & 67.97 \\
Average & 73.25 & 60.14 & 67.74 \\
\hline \hline
\end{tabular}

\section{H. Strain of TCL Slab}

The TCL slab strain of driving speed was shown in the figure 9. As to the driving speed of train, the trend was shown to be increasing from $100 \mathrm{~km} / \mathrm{h}$ to $236 \mathrm{~km} / \mathrm{h}$ and decreasing gradually after peak point, $236 \mathrm{~km} / \mathrm{h}$. The 
maximum value was $17.94 \mu \varepsilon$ about $18 \%$ of $100 \mu \varepsilon$ which is design standard of maximum strain for highspeed railroad structures. Therefore the stability of railroad structure of test-bed for high-speed railroad was enough to perform its design purpose.

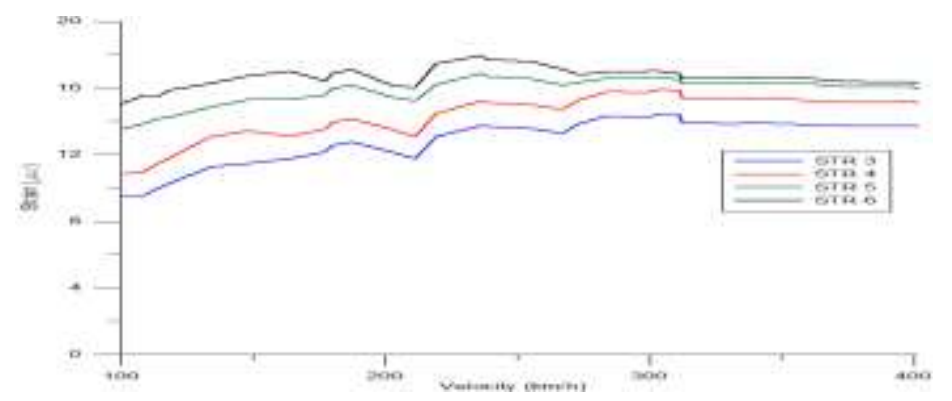

Fig. 9. TCL Slab Strain of Driving Speed Train

The TCL slab stress of driving speed was shown in the figure 10. The bending tensile stress of the slab was calculated using strain date and specification of slab. And the maximum stress was $0.54 \mathrm{MPa}$. In the concrete structure design standard of Korea, in case of being the roadbed compressive strength $50 \mathrm{MPa}$, allowable bending tensile stress should be under 3.7MPa.
The calculated value was about $18 \%$ of design standard of maximum strain for high-speed railroad structures. Therefore the stability of railroad structure of test-bed for high-speed railroad was enough to perform its design purpose.

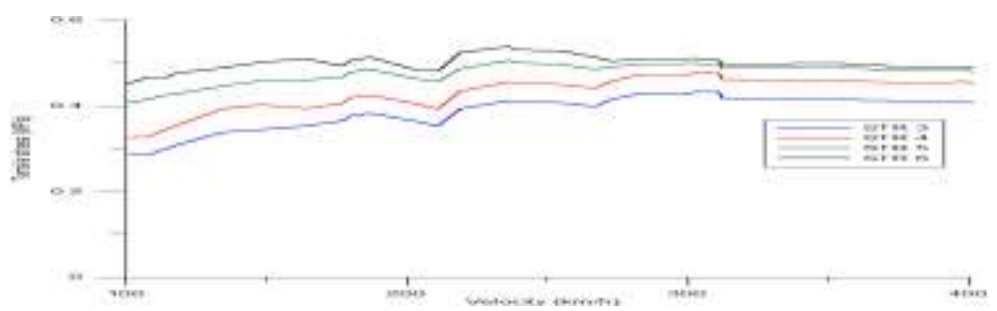

Fig. 10. TCL slab stress of driving speed train

The strain of concrete roadbed at bridge-earthwork transition zone of distance was shown in figure 11. As to strain of distance, it appeared to increase from bridge to earthwork as a bridge. This phenomenon happened to track support rigidity and was decreased from bridge to earthwork so that settlement was increased with strain and stress.
Moreover, it was changed from $13.75 \mu \varepsilon$ to $17.94 \mu \varepsilon$ at $236 \mathrm{~km} / \mathrm{h}$ to $401 \mathrm{~km} / \mathrm{h}$ with low inclination. The wheel load was distributed from concrete abutment of bridge to earthwork, because the approach slab at bridge-earthwork transition zone was connected between bridge and earth. Through this, the structure at transition zone was prevented to face the sudden rigidity transition.

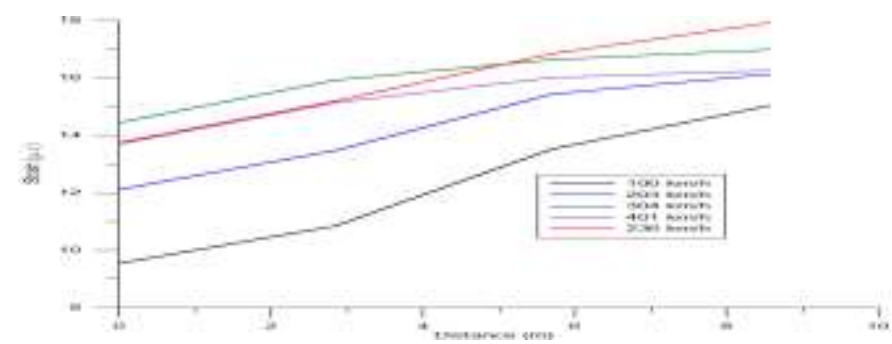

Fig. 11. TCL slab strain of distance 


\section{Vertical Displacement of Slab}

The total vertical displacement of the top slab according to the distance of the bridge-earthwork transition zone was equaled to settlement. The displacement meters were installed three on the center of top approach slab, top of concrete reinforced approach block-earthwork and top of normal earthwork. These locations were shown in the figure 5. The calculated settlement by theory and measured settlement were shown in the figure 12 .

Comparing the actually measured value with theoretical, as changing the structure of the support par the similar trend where the displacement increases was shown. In the case of center of top approach slab, the difference of $0.55 \mathrm{~mm}$ happened. The maximum value of the measured value was $0.92 \mathrm{~mm}$ whereas the theoretical result of calculation was $1.47 \mathrm{~mm}$. In the case of the top of approach block upper part, the difference of $0.52 \mathrm{~mm}$ happened. The maximum value of the measured value was $0.99 \mathrm{~mm}$ whereas the theoretical result of calculation was $1.51 \mathrm{~mm}$. Finally, in normal earthwork, the difference of $0.55 \mathrm{~mm}$ happened. The maximum value of the measurement was $1.03 \mathrm{~mm}$ whereas the theoretical result of calculation was $1.58 \mathrm{~mm}$. In each part, the theoretical result of calculation and measured value revealed the fixed difference and this difference was the result that it was generated actually in the different wheel load with the calculation. And the vertical displacement was proportionally changed with variation of wheel load.

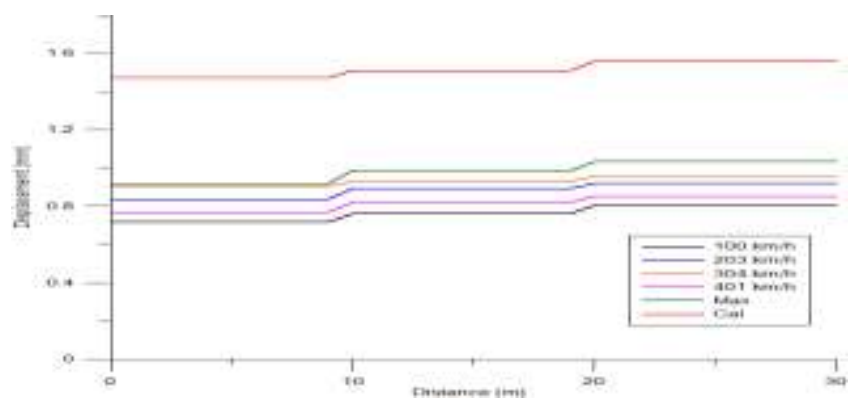

Fig. 12. Vertical displacement of bridge to earthwork

\section{J. Stability Evaluation}

The result of stability examination with the measurement assessment was performed comparing the criteria of measurements. And the concrete roadbed slab at bridge-earthwork transition zone in test-bed satisfied the criteria in environment of driving in $400 \mathrm{~km} / \mathrm{h}$ class of train. The result was shown in table 8 .

TABLE 8

RESULT OF STABILITY

\begin{tabular}{cccccc}
\hline \hline Subjective & Objective & $\begin{array}{c}\text { Measurement } \\
\text { Type }\end{array}$ & $\begin{array}{c}\text { Maximum } \\
\text { Value }\end{array}$ & Criterion & Result \\
\hline Track & Rail & Wheel load & $74.26 \mathrm{kN}$ & $\leq 200 \mathrm{kN}$ & OK \\
Support & TCL Slab & Strain & $17.94 \mu \varepsilon$ & $\leq 100 \mu \varepsilon$ & OK \\
Rigidity & Top Slab & Settlement & $1.03 \mathrm{~mm}$ & $\leq 3 \mathrm{~mm}$ & OK \\
\hline \hline
\end{tabular}

\section{CONCLUSION}

In this research, the stability of the test-bed infrastructure which was applied to the technology of high-speed railroad structure was evaluated according to development of the next generation high-speed train. The test-bed was consisted of connection between PSC Box bridge and earthwork section with concrete roadbed slab at bridge-earthwork transition zone. And by using the

Zimmermann Model, settlement was calculated theoretically. Then, Stability examination with the measurement value was performed.

The theatrical result of total vertical displacement (settlement) according to the track support rigidity of three parts was shown to have a difference of $0.11 \mathrm{~mm}$ 
from $1.47 \mathrm{~mm}$ to $1.58 \mathrm{~mm}$. These results can be forecasted to satisfy recommendation design criterion of 0.3 and do not need to be considered for the additional evaluation for design in bridge-earthwork transition zone.

The result of strain and wheel load test on the concrete roadbed slab at bridge-earthwork transition zone were similar in trend. The wheel load was increased to $236 \mathrm{~km} / \mathrm{h}$ and decreased to $3.9 \mathrm{~kg}$ per $1 \mathrm{~km} / \mathrm{h}$ with acceleration of train. Additionally, strain was changed from $13.75 \mu \varepsilon$ to $17.94 \mu \varepsilon$ at $236 \mathrm{~km} / \mathrm{h}$ to $401 \mathrm{~km} / \mathrm{h}$ with low inclination by distance of track. These results can be induced; the wheel load was distributed from concrete abutment of bridge to earthwork, because the approach slab at bridge-earthwork transition zone was connected between bridge and earth. Through this, the structure at transition zone was prevented by the sudden rigidity transition.

\section{REFERENCES}

[1] P. Sharp, R. J. Armitage, W. G. Heggie and A. Rogers, "Innovative design of transition zones," in Proceedings of the International Conference Railway Engineering, 2002.

[2] S. Y. Jang and S. C. Yang, "Assessment of train running safety, ride comfort and track serviceability at transition between floating slab track and conventional concrete track," Journal of the Korean Society for Railway, vol. 15, no. 1, pp. 48-61, 2012. DOI: $10.7782 / \mathrm{jksr} .2012 .15 .1 .048$

[3] K. Y. Eum, Y. H. Kim and J. W. Kim, "Study on dynamic characteristics of structure approaches by train moving loads," Journal of the Korean Society for Railway, vol. 16, no. 4, PP. 298-304, 2013. DOI: 10.7782/JKSR.2013.16.4.298

[4] S. C. Yang, S. Y. Jang and E. Kim, "Determination of upper limit of rail pad stiffness for ballasted and concrete track of high-speed railway considering running safety," Journal of the Korean Society for Railway, vol. 14, no. 6, 526-534, 2011. DOI: 10.7782/JKSR.2011.14.6.526

[5] VTRC 00-R4, "Guidelines for the use, design, and construction of bridge approach slabs," 1999.

[6] D. Li and D. Davis, "Transition of railroad bridge approaches," Journal of Geotechnical and Geoenvironmental Engineering, vol. 131, no. 11, pp. 1392-1398, 2005.
Maximum ration of Theoretical value of displacement (settlement) with measured value was $37 \%$. And the concrete roadbed slab at bridge-earthwork transition zone in test-bed satisfied the criteria in environment of driving in $400 \mathrm{~km} / \mathrm{h}$ class of train.

Original monitoring plan will be measuring at maximum speed, $430 \mathrm{~km} / \mathrm{h}$, but the speed of train was $400 \mathrm{~km} / \mathrm{h}$ because the train was made for test. Moreover, monitoring data can be disordered easily with environment as atmosphere temperature, humidity, degradation, temporal characteristics of the material, etc. So the additional longterm monitoring to approach $430 \mathrm{~km} / \mathrm{h}$ is needed.

Although this research was needed for additional tests in long-term, measurement of DB through the monitoring system in this research will be applied for the design of super high-speed railroad infrastructure.

DOI: 10.1061/(ASCE)10900241(2005)131:11(1392)

[7] UIC Code719R, Transitions between Structures and Earthworks, 3rd ed., 2005.

[8] UIC Code774-3R, Track \& Bridge Interaction 3rd ed., 2005.

[9] Ministry of Land and Transport, "Design standards for railway structures and commentary-Limit for displacement," Railway Technology Research Institute, 2006.

[10] J. Briaud, R. W. James and S. B. Hoffman, "Settlement of bridge approaches (the bump at the end of the bridge," NCHRP Synthesis 234. Washington D.C, USA, 1997.

[11] College of Eng, "Movement and settlements of highway bridge approaches," Kentucky Transportation Center, Kentucky, USA, 2002.

[12] Ministry of Land and Maritime of Korea, "Standards for railway vehicle safety criteria," 2008.

[13] C. Y. Choi, H. S. Park, K.L. Lee and D.W. Kim, "Management criterion and performance lever of the bridges transitional section in high speed railway," in Proceeding of the Korea Society for Railway, 2012, pp. 363-368

[14] Y.S. Ham. A study on running speed and reduction value in vertical wheel load of rolling stocks," in Proceeding of the Korean Society of Mechanical Engineers, 2009, pp. 772-775. 